\title{
Regional Parliaments Questioning EU Affairs
}

Anna-Lena Högenauer

The full article will appear in the Journal of Legislative Studies, July 2017.

\section{Abstract}

Since the Treaty of Lisbon, the desire of parliaments to adapt to their new powers has led to a new wave of Europeanization (Hefftler et al. 2015). However, the Early Warning System (EWS) and the Political Dialogue with the Commission only constitute one small part of parliamentary scrutiny for regional parliaments, which still largely rely on traditional tools such as mandates, debates and questions. Therefore, this paper studies a traditional mechanism of scrutiny, parliamentary questions, in order to understand the degree of Europeanization of regional parliaments and their interest in different parliamentary functions more fully. The study shows that the Europeanization of traditional scrutiny mechanisms is progressing slowly, but also that the proportion of MPs who ask EU-related questions is now relatively high. The vast majority of these MPs are not members of the European Affairs Committee. The main functions of parliamentary questions are a representative function and information function. Finally, the focus and content of parliamentary questions show that regional parliaments do indeed have a distinctive territorial approach to EU affairs.

\section{Introduction}

Since the early 2000s, academic interest in the role of national parliaments in European policymaking has sharply increased. Policy-makers discussed whether the democratic deficit could be solved by reforms of European institutions alone or whether the democratic legitimacy of national parliaments was a necessary ingredient. Academics focused more on the degree of Europeanization of national parliaments, their capacity to engage in European affairs scrutiny, different styles of engagement, the influence of national parliaments or lack thereof and interparliamentary cooperation (e.g. Maurer and Wessels 2001; Auel and Benz 2005). The provisions on new competences for national parliaments in the failed Constitutional Treaty and successful Lisbon Treaty further fueled this debate and led to further research consortia such as OPAL and more individual scholarship on the adaptation of national parliaments to Lisbon and on whether the Lisbon provisions went far enough to make a difference (e.g. Hefftler et al. 2015). Thus, in Protocols No 1 and 2 of the Lisbon Treaty, national parliaments gained extensive information right and the right to scrutinize new legislative proposals on whether they respected the principle of subsidiarity (the Early 
Warning System - EWS). In addition, in anticipation of the Lisbon Treaty, the President of the European Commission invited national parliaments in 2006 to participate in a political dialogue with the Commission. While the political dialogue is purely consultative, the EWS was criticized for presenting high hurdles for effective action, while at the same time only promising limited influence (Raunio 2011).

The Lisbon Treaty also strengthened the role of regional parliaments, but in a more modest way. Protocol No 2 mentions that national parliaments may consult regional parliaments with legislative powers in the Early Warning System, but it does not make it mandatory. The impact on academic research was initially also modest. While most of the studies pre-Lisbon were single country studies or collections of case studies loosely framed by general chapters (Heggie 2006; Carter and McLeod 2005; Abels and Eppler 2011; Hrbek 2010), post-Lisbon scholarship has focused mostly on the adaptation of regional parliaments in terms of procedures (Vara Arribas and Bourdin 2011; Abels 2013; Abels and Eppler 2014). Now - with some delay compared to national parliaments - the first studies on the activities of regional parliaments post-Lisbon appear (e.g. Boronska-Hryniewiecka 2013; Vara Arribas and Högenauer 2015). However, most of the literature is pessimistic as to the extent of regional parliamentary engagement in practice. Be it the lack of incentives or the lack of capacity, a large number of regional parliaments have still not used their new powers (Vara Arribas and Bourdin 2011; Buzogany and Stuchlik 2011; Boronska-Hryniewiecka 2013). Even where parliaments undergo thorough institutional reform, participation in practice can remain low, as demonstrated by the Scottish case (Högenauer 2015).

The fact of the limited use of the EWS by regional parliaments should draw academic attention back to traditional means of parliamentary control, for example control of the regional executive. The governments of legislative regions are usually involved in domestic EU policy-making and often in policy-making in Brussels. In the case of national parliaments, there is an extensive literature on the use of traditional parliamentary instruments such as mandates, debates and question for the purpose of EU affairs scrutiny (Raunio and Wiberg 2010; Navarro and Brouard 2014; Hefftler et al. 2015). In addition, Gattermann et al. have noticed a trend towards the mainstreaming of parliamentary scrutiny in Europe in the case of national parliaments. Increasingly, formal powers for scrutiny are delegated to sectoral committees rather than European Affairs Committees (EACs), which may also affect the organization of parliamentary staff and the selection of MPs for participation in interparliamentary cooperation. Gattermann et al. expect the mainstreaming of European affairs to a wider range of committees to also result in wider interest in European affairs within a parliament, i.e. in a larger number of MPs taking up European issues (2013). 
By contrast, in the case of regional parliaments, the academic analysis of the actual use of traditional parliamentary instruments is still underdeveloped. However, how these instruments are used and by whom can tell us a great deal about the Europeanization of a parliament. Similarly, we know very little about the extent to which regional parliaments are mainstreaming EU affairs. A survey of the staff of 23 regional parliaments from six member states in the context of a different study (Högenauer et al. 2016) showed that sectoral committees were responsible or partially responsible for EU affairs in five parliaments. The effects of this mainstreaming have not been studied.

This contribution focuses on written questions, which have a number of advantages as an object of research: They exist in all parliaments and are thus relatively comparable across countries and legislatures (Norton 1993). They tend to be well-documented. And they can be used by individual MPs irrespective of party or committee membership and thus reveal how wide-spread interest in European issues really is. Methodologically, written questions can thus reveal both who is asking the questions, and how they are being used. This is of particular interest if we seek to understand to what kind of a role regional parliaments play in EU affairs (cf. Introduction to this volume), for example whether their work has a distinctive territorial focus compared to national parliaments.

This paper thus seeks to address three interrelated questions: To what extent is the work of regional parliaments Europeanized? What functions do parliamentary questions on EU affairs fulfill? And to what extent do regional MPs have a distinct perspective on EU affairs. These questions are analyzed through the cases of Scotland and Bavaria on the basis of data on written questions for the years 2012-2014. ${ }^{1}$ The contribution will first discuss the literature on the functions of parliamentary questions. It will then discuss the hypotheses and case selection. The following sections will analyze the degree of Europeanization of the two regional parliaments and how they make use of written questions.

\footnotetext{
${ }^{1}$ EU-related questions were identified with the search machine of the Scottish parliament by using the search term 'euro' (i.e. covering Europe, European, Euro...).

In the case of the Bavarian parliament, the search terms 'europäische' and 'europäischen' were used, as the search machine only recognizes complete words.

It is possible that questions may have been overlooked if the question referred to a Directive or Regulation without mentioning Europe. However, as both search machines also selects those questions for which only the answer contains the search terms, the number of omitted questions is likely to be low. The results were then coded manually.
} 


\section{The function of parliamentary questions}

Parliamentary question are an instrument used by virtually all legislatures and usually in great numbers - in the case of national parliaments easily in the tens of thousands per year. This popularity stems in part from the fact that they can be tabled by individual MPs or smaller groups of MPs. With the exception of questions during the mediatized 'Question Hours', parliamentary questions in general and written questions in particular are one of the instruments that experiences the lowest degree of party pressure, leaving MPs free to focus on the issues that interest them most (Rasch 2011). They can also be tabled on any topic irrespective of committee membership. As MPs face so few constraints when they use this tool, the study of questions is an ideal to study the preferences and priorities of MPs (Navarro and Brouard 2014) as well as the representative, legislative or scrutiny focus adopted by the questioners. An analysis of parliamentary questions thus also bridges to some extent the divide between the majority of the literature on parliaments in EU affairs, which tends to focus on control and legislative powers, and the emerging communicative turn, which so far focuses primarily on representation and parliamentary debates (e.g. Auel 2014; Auel and Raunio 2014; Wendler 2013). In addition, questions allow us to study whether MPs have an international or national policy interest or a constituency orientation (Martin 2011).

In the literature, there is a recurrent assumption that parliamentary questions serve a control function (e.g. Wiberg 1994). This is a logical assumption, if one considers that a parliamentary question is a request for information/explanations that is addressed to a member of the executive by a member of parliament. However, many studies simply focus on the number of questions rather than their content and wording, so that their true purpose is still relatively unknown (Martin 2011). Thus, in practice, the potential of written questions to reveal the preference and role orientation of MPs remains underexplored.

In practice, written questions could serve one or more functions, and which functions they serve can depend on national culture (cf. Rozenberg et al. 2011):

a) A control function, with the aim of imposing parliamentary accountability on government (Wiberg 1994; Lazardeux 2005; Proksch and Slapin 2011). From a principal-agent perspective, voters delegate authority to MPs who delegate it to government. Parliamentary questions are an important tool for obtaining information from the government on policy development and implementation and for ex-post control (Martin 2011; Saalfeld 2000).

b) A legislative function: By asking the government how it intends to address a certain issue, MPs can put pressure on the government to actively engage in a policy-making process to achieve a certain result. 
c) A representative function: By highlighting concerns of constituents and pushing local issues onto the agenda (representative function) (Martin 2011). However, this function is disputed by Lazardeux in the case of France (2005).

d) An information function: By asking for information on a policy or state of affairs more generally (Lazardeux 2005; Navarro and Brouard 2014).

In addition, written questions can reveal the level of politics that MPs are most interested in: do they ask about local/regional issues, national issues or international issues? Even in a study of questions on EU affair, such as this one, this distinction is still relevant. Some MPs may be interested in how a policy affects the United Kingdom (national), some may be interested only in its effect on Scotland or even Edinburgh (regional/local), and some may worry about the EU as a whole or its impact on nonEuropean countries. Thus, by looking at the content and/or style of question, it is possible to see whether an MP is constituency-oriented (Martin 2011). In that case, there should be references to a constituency in an important proportion of questions.

\section{Expectations}

This study focuses on three questions: the first question of interest is to what extent the regional parliaments are Europeanized. This will be measured by two indicators: the proportion of parliamentary questions that are related to EU affairs; and the proportion of MPs who asked a question on EU affairs in a given year.

Secondly, the contribution analyses which perspective regional MPs tend to adopt in their questions, and thus how MPs fulfil their representative function. In particular, the section focuses on who is being represented - the subregion, the region or the concerns of the member state? This will also allow us to assess whether regional parliaments can play a role in EU affairs scrutiny that is distinct from the role of national parliaments. A second variable will analyze at which stage MPs ask questions about EU policies - at the policy-making or at the implementation stage? This question is of interest, as strong regions are often seen has playing an important role in the implementation of EU policies. A strong focus on implementation in regional parliaments would be a further confirmation of that role.

Finally, we are interested in the functions that written questions fulfill. For that purpose, we will analyze whether written questions on EU affairs are used as a tool to scrutinize the regional 
government or the EU, influence policy-making processes or simply gather information more generally.

With regard to the Europeanization of regional parliaments, the share of EU-related questions in the total number of written questions will most likely be low. As Raunio and Wiberg (2010) argue, the EU is of low salience to most citizens, so that MPs are under little pressure to ask EU-related questions. However, they also noticed a steady increase in the use of questions in general, which means that questions do appeal to MPs. Rozenberg and Martin (2011) expect written questions in particular to be a useful tool to ask about local issues and to received detailed, precise and opposable information from the executive. Based on the existing literature, some MPs can be expected to be more active than others:

a) Firstly, one can expect more questions from opposition MPs. Opposition MPs are at an informational disadvantage compared to government MPs, as they have fewer informal means to access information. In addition, they may wish to distance themselves from the policy of the government and to draw attention to blunders committed by the government (Sitter 2001).

b) One can expect more EU-related questions from MPs with a relevant policy specialism (European Affairs Committee or relevant sectoral committee, Raunio 1996). Thus, MPs who are already interested in a policy and well-informed in that policy area are more likely to investigate further.

In addition, one can also expect the characteristics of the two cases, Scotland and Bavaria, to shape the outcome of the study. Both cases are parliaments from strong legislative regions: Their governments are involved in the formulation of national positions in EU policy-making, and they both have to implement a wider range of EU policies. Both parliaments can thus be expected to be fairly active in EU affairs. Both parliaments are also elected through similar systems (a mix of proportional votes and constituency MPs), which allows us to study the differences between constituency and list MPs in a comparable environment.

However, the Scottish parliament is fully mainstreamed, i.e. sectoral committees are in charge of European issues that fall into their policy area (Carter and McLeod 2005). ${ }^{2}$ As a result, one can expect a wide range of MPs to be involved in EU affairs scrutiny. By contrast, in the Bavarian Landtag the competence for EU affairs scrutiny is shared between the EU affairs committee and sectoral

\footnotetext{
${ }^{2}$ Also Interview with an EAC clerk, Scottish Parliament, 1/04/2015.
} 
committees. The EU affairs committee is stronger, as it has a gatekeeping function. It generally decides whether there is a potential subsidiarity concern, whether Bavarian interests are affected and whether the parliament should become active in a matter. It then delegates those items to the sectoral committees (Bayerischer Landtag 2014). Unlike in the Scottish case, it thus reviews all EU dossiers, whereas the sectoral committees only review 'relevant' dossiers. Generally speaking, one would thus expect MPs from Scottish sectoral committees to ask more questions on EU affairs than Bavarian MPs from sectoral committees. Overall, this means that the Scottish Parliament is more likely to be extensively Europeanized than the Bavarian parliament.

In addition, the Scottish Parliament has more extensive legislative powers domestically, whereas Bavaria has some legislative powers but also many implementation powers as part of the cooperative German federal system. While European integration cripples the legislative function of regional parliaments by shifting powers to the European level, we would expect the Scottish Parliament to have a stronger focus on the legislative function than Bavaria, in line with its domestic powers.

\section{The extent of Europeanization}

In the years 2012-2014, Members of the Scottish Parliament (MSPs) logged a total of 16,312 written questions. Out of these, 245 were questions that explicitly referred to EU affairs. That represents only a share of 1.5 percent. This number may underestimate the real share of EU-related questions slightly, as duplicate questions were not coded. In other words, in those instances where an MPS had to ask a question several times with slight modifications to get an answer, only the successful question is being coded. Those cases are, however, very rare. In total the number of such instances was below five. While the share of EU related questions is generally low among European parliaments, this is low compared to - for example - the Finish parliament (about 3 percent, Raunio and Wiberg 2010) or the French parliament (about 4 pecent, Navarro and Brouard 2014).

\begin{tabular}{|l|l|l|l|l|}
\hline & 2012 & 2013 & 2014 & Total \\
\hline $\begin{array}{l}\text { EU-related } \\
\text { questions }\end{array}$ & 109 & 81 & 55 & 245 \\
\hline Total questions & 6311 & 5957 & 4044 & 16,312 \\
\hline $\begin{array}{l}\text { Percentage of EU } \\
\text { questions }\end{array}$ & 1.7 & 1.4 & 1.4 & 1.5 \\
\hline
\end{tabular}

Table 1: The share of EU-related written questions in the Scottish Parliament 
By comparison, out of around 2900 total written questions, 117 were EU-related in the Bavarian Landtag, which is a share of around 4 percent. ${ }^{3}$ Thus, contrary to our expectations, Scotland has a relatively low share of EU-related questions even compared to other regional parliaments.

However, if we look at the total number of Scottish MSPs who asked an EU-related question in this period, there is evidence of Europeanization. Thus, it seems to be the case that around one fifth to one quarter of MSPs take into account EU affairs every year (cf. table 2). The lower proportion of MSPs asking EU-related questions in 2014 may well be related to the Scottish referendum on independence, which raised some EU-related questions, but obviously also many more national questions (cf. table 1). Overall, the level of participation clearly goes beyond the circle of member of the European Affairs Committee (seven members in that period) and thus suggests that the decision of the Scottish Parliament to 'mainstream' EU affairs, i.e. to put sectoral committees in charge of EU affairs falling into their area of expertise, has produced an effect.

In the case of the Bavarian Landtag, a much lower proportion of MPs tabled an EU-related written question. In 2012, only around 10 percent of Bavarian MPs asked one or more EU-related questions. For 2013, the number is difficult to determine as the composition of the Landtag changed in the wake of an election. In 2014, there is an increase to 16.7 percent, which seems to be largely due to European debates about various funding instruments, which led to an increased interest in the amounts of EU funding spent on different Bavarian sub-regions.

\begin{tabular}{|l|l|l|l|l|}
\hline & & 2012 & 2013 & 2014 \\
\hline \multirow{2}{*}{$\begin{array}{l}\text { Percentage of total } \\
\text { MSPs }\end{array}$} & Bavaria & 9.6 & election year & 16.7 \\
\cline { 2 - 5 } & Scotland & 21.7 & 28.7 & 18.6 \\
\hline
\end{tabular}

Table 2: The share of MPs asking EU-related questions

To what extent can the fact that there is a higher proportion of EU-related questions in the Bavarian Landtag, but asked by a relatively small number of MPs, be explained by the fact that EU affairs scrutiny is officially still concentrated in the EAC, compared to Scotland which has mainstreamed EU affairs?

In fact, the analysis of Scottish written questions shows that the EAC itself is not particularly active. EAC members only account for 7.3 percent of the Scottish EU-related questions between 2012 and 2014. The vast majority of questions were thus asked by MSPs who were members of other

\footnotetext{
${ }^{3}$ The fact that the total number of questions in the Bavarian Landtag is much lower is at least in part due to the different format of questions. In the Scottish parliament, each written question is one single question. In the case of the Bavarian Landtag, MPs can bundle several related question into a single written question. In other words, one written question can contain multiple sub-questions.
} 
committees. In addition, only four of the full members of the EAC asked EU-related questions during this period. While two of them were very active in 2012, asking a total of 15 written questions on EU issues, the EAC members only asked two EU related questions in 2013 and one in 2014. 'Ordinary' MSPs have thus become even more dominant in the last two years. By comparison, Bavarian EAC members also only accounted for a minority of EU-related written questions. However, their share of 26.5 percent of all EU-related questions is much higher than in the case of Scotland.

Overall, while the extent to which the use of written questions is Europeanized is limited, the extent to which EU-related questions are submitted by 'ordinary' MPs who are not members of the EAC supports the claim by Gattermann et al. (2014) that European affairs scrutiny is no longer confined in the hands of European affairs committees and involves a wider range of MPs, especially in the case of the Scottish parliament, where EU affairs were extensively mainstreamed. But we can also find evidence of this in the case of Bavaria. At the same time, mainstreaming clearly does not automatically create a burning concern for EU affairs - as illustrated by the relatively low share of EU questions in the Scottish case.

\section{A distinctive perspective?}

Yet, if a wider range of MPs use written questions as a tool to follow up European issues today, the question remains as to their focus. This is an important issue, as it touches on the debate on what kind of a role regional parliaments can and should play in EU policy-making and who they represent. On the one hand, the involvement of regions and regional parliaments in EU policy-making is traditionally justified with the need to bring Europe closer to the citizens. There is thus an assumption that regional actors are particularly well-equipped to communicate European policies to the citizens, but also to carry the concerns of citizens into the European arena. On the other hand, the involvement of regional actors in policy-making makes policy processes longer, more complex and potentially less transparent, leading some authors to argue that it is unnecessary to involve (most) regional parliaments in EU policy-making. In this view, national representative democracy is seen to be qualitatively different from regional democracy, as citizens (in most cases) identify themselves more strongly with it Crum (2015). Thus, here, the aim is to analyze what kind of a role regional parliaments currently do play through the prism of parliamentary questions.

For this purpose, one needs to assess to what extent regional parliaments have a distinct territorial perspective, as broader questions about the strengths and weaknesses of European policies and institutions could also be asked by any other parliamentary actor. In order to establish the 
territorialization of the parliamentary questions, the questions were coded based on whether they contained an explicit reference to a geographic location or actor at the national, regional or subregional level. To illustrate this with two examples: The question 'How does the Commission evaluate the impact of fertilizer A on the environment? What action does it plan to take?' would express a general (presumably European) concern. The question 'What will the costs of Directive $\mathrm{X}$ be for Scotland?' would be a regional concern.

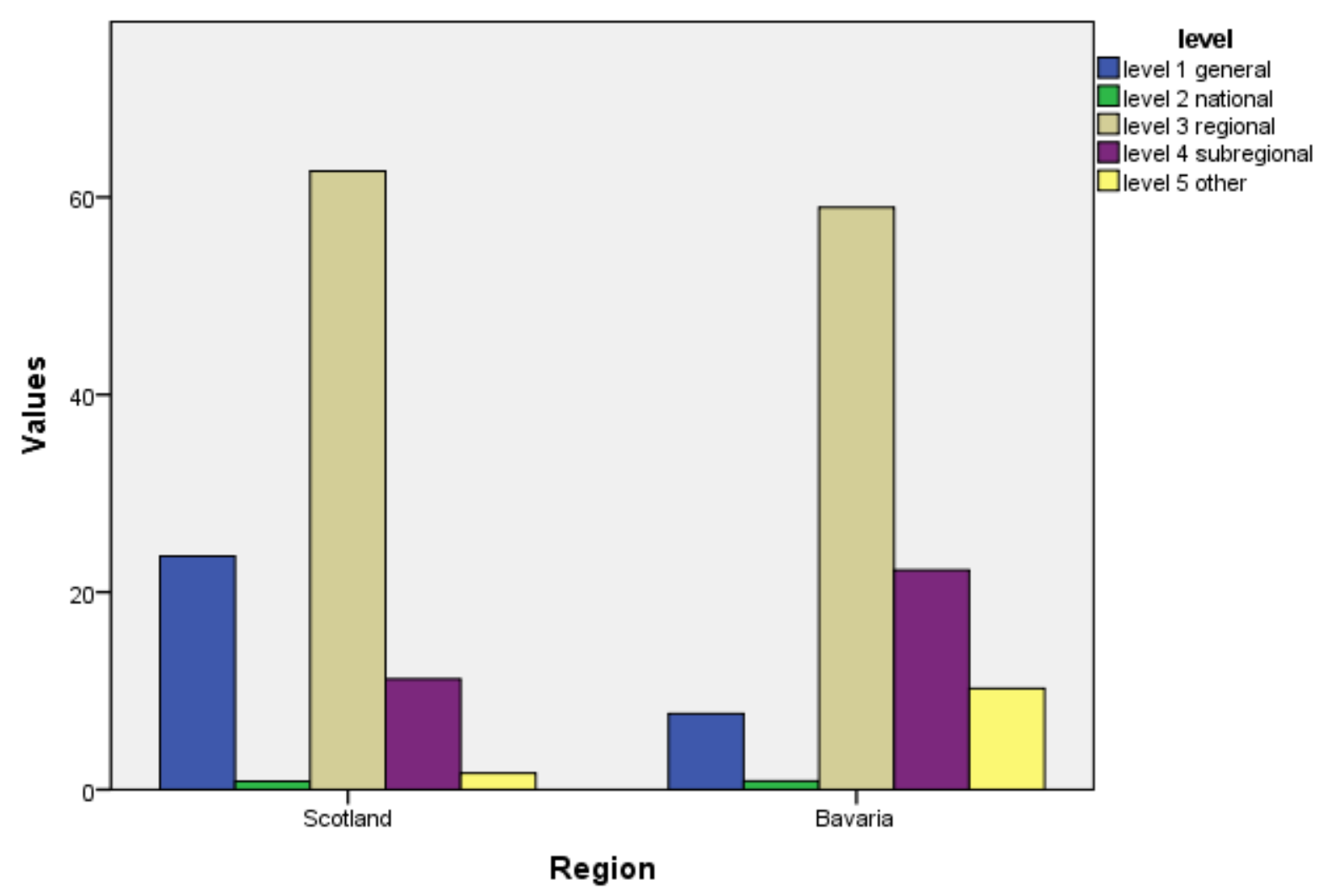

Chart 1: Level of concern in the written questions

As is clear from chart 1, the vast majority of questions focus on how the European issue plays out on the regional level. The pattern is very similar in both regions in that respect. Around 60 percent of the question focus directly on the regional level, with an additional 10-20 percent of questions focusing on subregions or even smaller areas. In addition, many of the 'other' questions focus on specific actors (e.g. a company, an association) in relation to the European issue. In addition, neither of the two parliaments adopt a national perspective on EU affairs. Both parliaments have thus a very distinctive regional territorialisation that connects European issues with regional or local politics. The 
main difference is that Bavarian MPs focus a little more on their electoral districts (e.g. Swabia, Lower Bavaria etc.), whereas Scottish MSPs focus a little more on the general European dimension (e.g. how does this Directive work in general?). Thus, contrary to the expectation that the referendum might have led to an increased interest in Scotland-related questions (EU membership, Euro etc.), Scottish questions are on balance still slightly less regionalist than Bavaria. Nevertheless, there are around 40 questions are about independence, although not all of these focus just on the regional level and the impact on Scotland. On the whole, regional MPs fulfil a representative function in their question, but they focus on the region as a whole, and only to a lesser extent on a specific sub-region.

The strong regional and sub-regional focus does indeed set regional MPs apart from national MPs. The literature on the regional/local focus of questions in national parliaments is admittedly somewhat underdeveloped, which complicates the comparison. As Martin (2011: 262) points out, many authors simply assume that parliamentary questions do not serve the purpose of 'cultivating relationships with constituents', but look at total number of questions rather than their actual content. A good example of this approach is Lazardeux (2005), who essentially guesses whether there might be a strong constituency link based on how rural the constituency is and how well educated the voters are. That said, Russo (2011) shows that one third of parliamentary questions by Italian MPs refer to the region of the MP - i.e. far less than the 70-80 percent of regional and subregional questions in the Scottish and Bavarian case. Rozenberg et al. (2011) study the territorial focus on defense questions, and find that in the UK and Germany only about 20-22 percent of parliamentary questions have a local focus. However, this study is not quite comparable, as it focuses only on one policy area.

Another indicator that is very much in line with the regional focus of regional parliaments is the fact that parliamentary questions focus on the implementation stage rather than the policy-making stage. About 20 percent of the questions cannot be classified as being about 'policy-making' or 'implementation', as they are about broader issues. However, looking at the remaining questions, in the case of Scotland almost 80 percent of these are about implementation, whereas almost 90 percent of the German questions are about implementation. This reflects the role of regions in the EU multi-level system. In the course of devolution, Scotland has gained many 'exclusive' competences, but in practice they overlapped considerably with some of the most densely regulated policy areas in EU politics (e.g. the environment, fisheries, agriculture etc.). Thus, in practice, Scotland is now responsible for the implementation of many of the European laws. Similarly, in the German cooperative federal system, the Länder have many shared powers that overlap with EU 
competences. Thus, the overwhelming majority of questions are about how those policies will be implemented. By contrast, the interest in the legislative phase of EU policies is extremely low.

\section{The functions of parliamentary questions}

If regional MPs thus have a very strong regional focus and are primarily interested in implementation, what does this mean for the function of parliamentary questions? Here, the typologies used in the literature (cf. second section) turned out to be of limited usefulness in practice. Firstly, during the coding, it became quickly apparent that neither Scottish nor Bavarian questions fulfil a legislative function, in the sense that they would push the government to do something. This differentiates the Scottish Parliament from the House of Commons, for example, where MPs do sometimes try to make the government change course or consider a new policy problem, especially in oral questions. The finding is unsurprising, if one considers that very few questions are about the legislative stage of EU policies (cf. previous section). Instead, the vast majority of Scottish and Bavarian questions asked for information and could at best be categorized as fulfilling a control function. Thus, after a pilot, the coding was adapted to include four categories: asks for information about the policy in general, asks for information about the position of the regional government, asks for information about the actions/plans for action of the government, criticizes the government or expresses a concern with the current situation. The first of these points corresponds to a mere information function. The second and third categories serve mainly an information function, but the information obtained can help the MP exercise a control function at a later stage. The final point (criticism/concern) falls the most clearly into the control function. In the event that a question could be interpreted as falling into two categories, it would be coded as belonging to the more 'ambitious' category. For example, if a question asked for information about a policy and the government's stance on the policy, it would be coded as asking about the government's stance. If a question asked about the actions of the government and expressed criticism, it was coded as criticism.

As chart 2 illustrates, about half of the questions asked only for more information about the actions or plans for action of the governments. What is interesting in that respect is that these questions are used mainly for the purpose of gathering information. Questions that were overtly critical of the government or European level or that expressed concern over an issue were coded as 'criticism or concern'. In the case of Scotland, none of the questions fell into that fourth category of clear criticism of the government. This has probably to do with the fact that Scottish written questions tend to be 
very short and thus do not provide the opportunity to express criticism. By contrast, around 13 percent of the Bavarian questions were critical. This is facilitated by the format of the questions, whereby MPs can provide a lengthy introduction about how the situation is deteriorating with regard to $x$, which them allows them to ask fairly aggressive questions. Nevertheless, questions that seem to simply ask for information may of course be used to gather ammunition to attack the government at a later stage, for example in plenary debates.

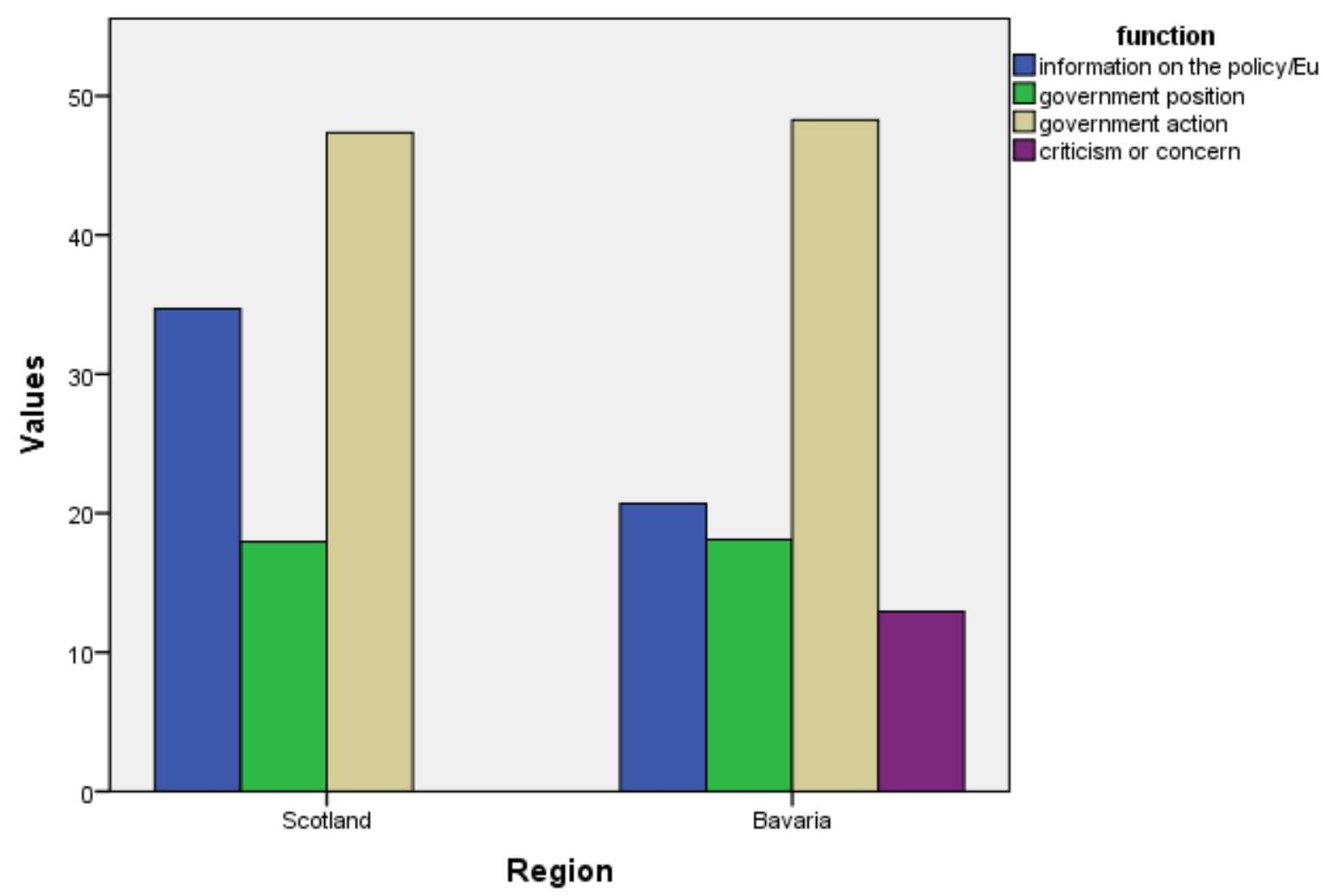

Chart 2: The aim of the question

As a result, the data highlights again a specific function of regional institutions. The multi-level governance literature generally presents regions as the key implementing authorities and regions themselves demand more influence by pointing towards their role as implementing authorities. The parliamentary questions reflect the extent to which regional institutions focus on that role and are interested primarily in how the government intends to implement EU policies. In addition, the limited number of overtly critical questions also suggests that written questions are rarely used to directly exercise a control function over the government. One should nevertheless note that there is a strong 
government-opposition dynamic in the use of written questions. In the Scottish case, the SNP has only asked 11.8 percent of the EU-related written question. The Bavarian CSU has been even less active, asking a grand total of four EU-related questions in three years. This suggests that the questions are indeed a tool for the opposition to gather information that will allow MPs to later control the government with other tools.

\section{Conclusions and Outlook}

To conclude, this paper has argued that studies on the role of regional parliaments in European affairs need to look more at the activities of regional parliaments, as formal rules can be deceptive. Institutional reforms - even if carefully prepared - do not always translate into concrete action. The Early Warning System is a prime example of the gap between formal powers and their actual use. In addition, the traditional tools of parliaments allow a research to study a wider range of parliamentary functions and to take into account the positions of individual MPs.

The goal of this study was to make a step in this direction by analyzing the use of written questions in EU affairs scrutiny. The cases of Scotland and Bavaria both show that the Europeanization of traditional mechanisms of scrutiny is in practice also progressing slowly. The number of questions about EU affairs is low compared to the total number of written questions. However, the proportion of MPs who ask an EU-related question during a year gives reason for caution optimism. Also, the vast majority of these MPs are not member of the EAC, which shows that there is in fact awareness of EU affairs among other MPs outside the EAC. However, awareness is not the same as interest, and does not directly translate into a high level of activism.

Most importantly, an analysis of the focus and content of parliamentary questions has shown that regional parliaments do indeed have a distinctive approach to EU affairs. Firstly, the overwhelming majority of questions create a strong link between EU affairs and regional or subregional politics. The actions of the member state in general or the effects on the member state as a whole play almost no role in regional parlaiments. Secondly, the written questions reflect the constitutional position of regions in the European multi-level system of governance: a substantial number of parliamentary questions in the two regional parliaments focus on the transposition or implementation of EU policies, while policy formulation and negotiation plays a secondary role. Overall, this suggests that regional parliaments can indeed have an added value in EU affairs scrutiny that distinguishes them from national parliaments: they cater to a different set of interests. 
In terms of the functions of parliamentary questions, MPs use written questions to facilitate the control of their government and its implementation of EU policies. While there are relatively few overtly critical EU-related questions, there is a strong government-opposition dynamic, whereby governing parties ask very few questions. While this may in part be due to the better information flow between governments and governing parties, it also suggests that opposition parties use questions as a tool to gather information that will assist them in their control function. By contrast, there are only few questions that try to push the government in a certain direction. Written questions are thus used much more to represent and facilitate control than to engage in legislative functions.

\section{Bibliography}

Abels G. and A. Eppler (eds.) (2011), Auf dem Weg zum Mehrebenenparlamentarismus? Funktionen von Parlamenten im Politischen System der EU. Baden-Baden: Nomos.

Abels G. (2013), Adapting to Lisbon: Reforming the Role of German Landesparlamente in EU Affairs. German Politics, 22(4), 353-78.

Abels G. and Eppler A. (2014), Subnational Parliaments in an EU Multi-level Parliamentary System: Taking Stock of the Post-Lisbon Era. Studienverlag Innsbruck und Transaction Publishers New Jersey, USA, Foster Europe International Studies Series vol. 3.

Auel K. (2014) De-Parliamentarisation Re-Considered: Parliamentary Communication in EU Affairs; Workshop on National Parliaments in the EU, Delmenhorst, 6-7 March.

Auel, K. and Benz, A. (2005) 'The Politics of Adaptation: The Europeanisation of National Parliamentary Systems', Journal of Legislative Studies, 11(3-4): 372-93.

Auel K. and Raunio T. (2014) Debating the State of the Union? Comparing Parliamentary Debates on EU issues in Finland, France, Germany and the United Kingdom. Journal of Legislative Studies 20(1) $12-28$.

Bayerischer Landtag (2014), Beschluss: Änderung der Geschäftsordnung für den Bayerischen Landtag, Drucksache 17/4742, 10 December 2014.

Boronska-Hryniewiecka, K. (2013), Subnational parliaments in EU policy-control: Explaining the variations across Europe, EUI Working Paper RSCAS 2013/38.

Buzogany A., Stuchlik A. (2011), Paved with Good Intentions. Ambiguities of Empowering SubNational Parliaments after Lisbon, FÖV Discussion Paper No. 66, Speyer, German Research Institute for Public Administration, Speyer.

Carter, C. and McLeod, A. (2005) 'The Scottish Parliament and the European Union: Analysing Regional Parliamentary Engagement', In: S. Weatherill and U. Bernitz (eds.), The Role of Regions and Subnational Actors in Europe. Oxford: Hart Publishing, pp. 67-88. 
Christiansen T., A.L. Högenauer and C. Neuhold (2013), National Parliaments in the Post-Lisbon European Union: Bureaucratization rather than Democratization?, Comparative European Politics, doi:10.1057/cep.2012.38, 14 January 2013.

Gattermann K., A.L. Högenauer, A. Huff (2013), "National Parliaments After Lisbon: Towards Mainstreaming of EU Affairs?" OPAL Online Paper No. 13/2013.

Hefftler C., C. Neuhold, O. Rozenberg, J. Smith and W. Wessels (2015), The Palgrave Handbook on National Parliaments and the European Union, Palgrave, Basingstoke.

Heggie, G. (2006) 'The Scottish Parliament and the EU Constitution: Moving Beyond the Principle of Partnership', In: P. Kiiver (ed.), National and Regional Parliaments in the European Constitutional Order. Groningen: Europa Law Publishing, pp. 29-54.

Heitshusen V., Young G. and Wood D. (2005), Electoral Context and MP Constituency Focus in Australia, Canada, Ireland, New Zealand and the United Kingdom. American Journal of Political Science 49(1): 32-45.

Högenauer A.L. (2015) “The Scottish Parliament - An Active Player in a Multi-level European Union?” in G. Abels and A. Eppler (eds.), Subnational Parliaments in an EU Multi-level Parliamentary System: Taking Stock of the Post-Lisbon Era, Studienverlag Innsbruck und Transaction Publishers New Jersey, USA, Foster Europe International Studies Series vol. 3.

Högenauer A.L., Neuhold C., Christiansen T. (2016) Parliamentary Administrations in the European Union, Palgrave, Basingstoke.

Hrbek R. (ed.) (2010), Legislatures in Federal Systems and Multi-Level Governance. Nomos: BadenBaden.

Lazardeux S. (2005), 'Une question écrite pour quoi faire ?' The Causes of the Production of Questions in the French Assemblée Nationale, French Politics, 3, 258-81.

Martin S. (2011), Parliamentary Questions, the Behaviour of Legislators and the Function of Legislatures: An introduction, The Journal of Legislative Studies 17(3), 259-70.

Maurer, A. and Wessels, W. (eds) (2001) National Parliaments on their Ways to Europe. Losers or Latecomers? (Baden-Baden: Nomos Verlag).

Navarro J. and Brouard S. (2014), Who cares about the EU? French MPs and the Europeanisation of Parliamentary Questions, The Journal of Legislative Studies, 20(1), 93-108.

Norton P. (1993), Introduction: Parliament since 1960. In: M. Franklin and P. Norton eds., Parliamentary Questions. Oxford, Clarendon Press.

Proksch S.O. and Slapin J.B. (2011), Parliamentary Questions and Oversight in the European Union. European Journal of Political Research, 50: 53-79.

Rasch B.E. (2011), Behavioural Consequences of Restrictions on Plenary Access: Parliamentary Questions in the Norwegian Storting. Journal of Legislative Studies 17(3) 382-93. 
Raunio T. (1996), Parliamentary Questions in the European Parliament: Representation, Information and Control, Journal of Legislative Studies 2(4), 356-82.

Raunio T. (2011), The Gatekeepers of European Integration? The Functions of National Parliaments in the EU Political System. Journal of European Integration 33:3, 303-321.

Raunio T. and Wiberg M. (2010), How to Measure the Europeanisation of National Legislatures?, Scandinavian Political Studies 33(1), 74-92.

Rozenberg O. and Martin S. (2011), Questioning Parliamentary Questions, The Journal of Legislative Studies, 17(3), 394-404.

Rozenberg O., Chopin O., Hoeffler C., Irondelle B. and Joana J. (2011), Not only a Battleground: Parliamentary Oral Questions Concerning Defence Policies in Four Western Democracies, Journal of Legislative Studies, 17(3), 340-53.

Russo F. (2011), The Constituency as a Focus of Representation: Studying the Italian Case through the Analysis of Parliamentary Questions, The Journal of Legislative Studies 17(3), 290-301.

Saalfeld T. (2000) Members of Parliament and Government in Western Europe: Agency Relations and Problems of Oversight, European Journal of Political Research37(3) 353-76.

Sitter N. (2001), The politics of opposition and European integration in Scandinavia: Is Euroscepticism a government -opposition dynamic? West European Politics 24, 22-39.

Strom K., Müller W., Markham Smith D. (2010), Parliamentary Control of Coalition Governments, Annual Review of Political Science 13, 517-535.

Vara Arribas G. and Bourdin D. (2011), The Role of Regional Parliaments in the Process of Subsidiarity Analysis within the Early Warning System of the Lisbon Treaty, Brussels, Committee of the Regions.

Vara Arribas G. and Högenauer A.L. (2015), "Legislative Regions after Lisbon: A New Role for Regional Assemblies?" in: C. Hefftler, C. Neuhold, O. Rozenberg, J. Smith and W. Wessels, The Palgrave Handbook on National Parliaments and the European Union, Palgrave.

Wendler F. (2013) Challenging Domestic Politics? European Debates on National Parliaments in France, Germany and the UK. European Integration 35(7) 081-17

Wiberg M. (1994), To Keep the Government on its Toes: Behavioural Trends of Parliamentary Questioning in Finland 1945-90. In M. Wiberg ed. Parliamentary Control in the Nordic Countries: Forms of Questioning and Behavioural Trends. Jyväskylä: The Finish Political Science Association. 